\title{
Pesquisa em Educação: o debate modernidade e pós-modernidade*
}

\author{
Sílvio Gallo** \\ Unicamp - Departamento de Filosofia e História da Educação
}

resumo: $\mathrm{O}$ artigo discute as repercussões que o debate em torno de uma superação da modernidade e da suposta instauração de uma pós-modernidade traz para a educação como campo de conhecimento, mais especialmente para a pesquisa nesse campo. Discute-se criticamente a tese de que viveríamos na pós-modernidade, dada a ênfase dessa afirmação no âmbito do pensamento social, principalmente por compreender-se que essa expressão não tem a força e a intensidade de um conceito filosófico, acabando vazia de sentido. Para além do debate sobre o fim ou não da modernidade, opta-se pela noção de hipermodernidade, proposta por Lipovetsky, como forma de caracterização do mundo contemporâneo, buscando compreender suas implicações. $\mathrm{O}$ artigo trabalha as questões epistemológicas e políticas da discussão modernidade/pós-modernidade, com suas implicações para a pesquisa em educação. Conclui com uma tomada de posição em nome do pensamento e da criação no campo da pesquisa educacional.

palavras-chave: Modernidade; Pós-modernidade, Pesquisa em educação, Conceito.

abstract: This article discusses the effects that the debate on the overcoming of modernity and the supposed establishment of a postmodernity has on education as a knowledge field, especially on the research in this field. We propose a critical discussion on the thesis that we live in postmodernity, because of the importance given to such an idea in social thought. Our main point is that the expression 'postmodernity' doesn't have the strength or power of a philosophical concept, and thus it has no sense. Beyond the debate on the end or not of modernity, the notion of hypermodernity appears as an option. Proposed by Lipovetsky, it is a way to characterize the contemporary world, searching for its implications. In this article, we work on the epistemological and political issues of the modernity/ postmodernity discussion, as well as its meaning to education research. Finally, we conclude by taking a position on this discussion in the name of the thought and the creative power of the research in education.

keywords: Modernity, Postmodernity, Research in education, Concept.

\footnotetext{
* Texto preparado para a conferência com o mesmo título no IV Encontro de Pesquisa em Educação Ambiental (Rio Claro, 2007). Uma primeira versão, mais sintética, foi publicada com o título Modernidade/pós-modernidade: tensões e repercussões na produção de conhecimento em educação na revista Educação e Pesquisa, da FEUSP, v. 32, n. 3, set./dez. 2006.

**Contato: gallo@unicamp.br
} 


\section{Situando o debate}

Gostaria de situar o debate modernidade e pós-modernidade, tema deste evento, através das duas interrogações seguintes:

- Vivemos a crise da modernidade?

- Vivemos um "momento pós-moderno", como muitos discursos propagam?

Seu pano de fundo é o debate sobre o pós-moderno, suas implicações na filosofia contemporânea, suas decorrências para o campo da educação, em especial no que respeita à produção do conhecimento nesse campo. Não são poucos os que fazem a apologética da chegada dos “tempos pós-modernos” e da revolução que eles teriam causado no pensamento, na pesquisa educacional, nos modos de educar; por outro lado, também não é pequeno o contingente daqueles que criticam a "farsa pós-moderna”, esse canto de sereia que uma vez mais encobre o sol e obscurece nossa visão. Muito menor, porém, é o grupo daqueles que se dispõem a pensar, com a coragem e a seriedade necessárias, as transformações pelas quais passa o mundo e os desafios que se colocam a cada dia, para além da preocupação de classificar ou nomear esse momento, como se isso resolvesse os impasses.

No campo do pensamento social (penso aqui na Filosofia e nas ciências sociais de modo geral), fomos contaminados, desde meados da década de 70 do século XX, por essa expressão - pós-moderno; pósmodernidade; pós-modernismo - que advém dos meios artísticos, em especial da arquitetura, que faz todo o sentido neste contexto. Mas, de fato, não tem a força e a potência de um conceito. Alguns autores, em filosofia e em áreas afins das ciências humanas, tomaram e têm tomado expressões como "pós-moderno", "pós-modernidade" como se fossem conceitos; no entanto, tais expressões são filosoficamente vazias.

Essa é uma das teses que procurarei explicitar aqui. Para além disso, tentarei evidenciar as reais contribuições que tal debate traz, mesmo que um pouco "nublado" pela falta de intensidade conceitual, discutindo como essa tensão entre modernidade e pós-modernidade pode influir 
positivamente na produção de pensamento no campo da educação. Enveredarei por uma discussão de natureza epistemológica, depois, embora com menor intensidade e ênfase, por uma discussão de natureza política, para defender que não podemos permitir que essa tensão nos leve a uma paralisação do pensamento.

\section{Ambigüidades da expressão: a fraqueza não conceitual}

Em Pós-estruturalismo e filosofia da diferença (uma introdução), Peters (2000, p. 12-19) procura diferenciar conceitualmente pós-modernismo de pós-estruturalismo e, para isso, retoma a discussão entre modernismo e pósmodernismo. Argumenta que há dois sentidos para o modernismo, que pode ser abordado como movimento artístico, situado no final do século XIX e início do século XX, ou como movimento histórico-filosófico, sentido no qual seria uma espécie de sinônimo para "modernidade". Neste segundo sentido, pode-se afirmar que: "filosoficamente falando, o modernismo começa com o pensamento de Francis Bacon na Inglaterra e o de René Descartes na França” (PETERS, 2000, p. 12).

Assim, como termo derivado, o pós-modernismo também apresentaria dois sentidos; um como movimento artístico e outro como movimento histórico-filosófico. $\mathrm{O}$ autor recorre então ao Oxford English Dictionary, buscando o sentido e a etimologia da palavra, encontrando um sentido originário como movimento artístico do campo da arquitetura (com datações de uso do termo entre 1959 e 1980), só sendo estendido ao campo das ciências humanas a partir de meados dos anos 1970, com mais ênfase na década de 1980.

Se fizermos o mesmo movimento com um Dicionário da Língua Portuguesa, encontraremos a seguinte definição:

Pós-modernismo: denominação genérica dos movimentos artísticos surgidos no último quartel do século $\mathrm{XX}$, caracterizados pela ruptura com o rigor da filosofia e das práticas do Modernismo, sem abandonar totalmente seus princípios, mas fazendo referências a elementos e técnicas de estilos do passado, 
tomados com liberdade formal, ecletismo e imaginação. (DICIONÁRIO eletrônico Houaiss da Língua Portuguesa, 2001)

Fica clara, portanto, a origem do termo no campo da arte, como movimento artístico; apenas depois de se ter consolidado nesse campo é que deriva para as ciências humanas, fazendo então um trajeto inverso ao do termo modernismo.

$\mathrm{Na}$ literatura filosófica, o termo foi utilizado, não como substantivo, mas como adjetivo, por Jean-François Lyotard em obra publicada em 1979, cujo título original é A Condição Pós-Moderna. A tradução brasileira, publicada em 1986 e já no contexto de um razoável debate, optou pelo título O Pós-Moderno, o que faz toda a diferença. Já na introdução à obra, o filósofo delimita o campo de suas intervenções: o problema do conhecimento; e explica que a origem do termo que optou usar é norte-americana:

Este estudo tem por objeto a posição do saber nas sociedades mais desenvolvidas. Decidiu-se chamá-la de 'pós-moderna'. A palavra é usada, no continente americano, por sociólogos e críticos. Designa o estado da cultura após as transformações que afetaram as regras dos jogos da ciência, da literatura e das artes a partir do final do século XIX. (LYOTARD, 1986, p. xv, grifo nosso).

Nessa obra de Lyotard, duas são as teses fundamentais: a alteração no estatuto do saber e a falência dos "metarrelatos", evidentemente interrelacionadas. A primeira tese ele evidencia da seguinte maneira: "Nossa hipótese de trabalho é a de que o saber muda de estatuto ao mesmo tempo em que as sociedades entram na idade dita pós-industrial e as culturas na idade dita pós-moderna" (LYOTARD, 1986, p. 3). E ela leva à segunda tese, como decorrência: nesta "sociedade pós-industrial" e nesta "cultura pós-moderna", os metarrelatos (discursos filosóficos pretensamente universais) já não dão conta do real.

Não é meu objetivo discutir uma vez mais as teses de Lyotard, posto que isso já foi feito quase à exaustão. Se as trouxe à tona, foi apenas como registro daquela que muito provavelmente foi a primeira utilização 
filosófica da expressão "pós-moderno". Mas saliento que seu uso é mais adjetivo que substantivo, fato que a tradução brasileira esconde.

Coisa análoga aconteceu com outra obra posterior. Em 1983, o crítico norte-americano $\mathrm{Hal}$ Foster, redator associado da revista Art in América, publicou um interessante livro, com o título The Anti-Aesthetic: essays on postmodern culture ${ }^{1}$, reunindo textos de vários críticos e historiadores da arte, mas também de teóricos como Habermas, Jameson, Said, Baudrillard. Perceba-se que aparece, como subtítulo da obra, a expressão "cultura pós-moderna", no mesmo uso adjetivo feito por Lyotard. Já na tradução espanhola (não há versão para o português), o livro ganhou um título mais conciso: La Posmodernidad. Uma vez mais, efetua-se a operação, aparentemente inofensiva, de transformar o adjetivo em substantivo.

Por que insisto em demarcar essa operação? Porque, parece-me, quando se usa o adjetivo (como são os casos de Lyotard e de Foster), o pósmoderno aparece numa função auxiliar, que ajuda a definir um contexto e suas características; por outro lado, quando se usa o substantivo, a pósmodernidade ganha os ares de um conceito e, portanto, deveria apresentar densidade e intensidade. Penso não ser por acaso que os autores optaram pelo adjetivo; nas traduções, ao se optar pelo substantivo, subverte-se o sentido original dos textos, prometendo ao leitor algo que não é a proposta de origem.

Mas o que dizem, efetivamente, expressões como pós-moderno ou pós-modernidade? Elas designam, simplesmente, uma temporalidade: viveríamos hoje um tempo posterior à modernidade, um tempo que já não é o moderno. Mas o que seria esse tempo? Isso tais expressões não são capazes de dizer por si mesmas e, por isso, afirmo que elas não têm a potência do conceito, sendo filosoficamente "vazias". Corroboro minha afirmação com um texto recente de Lipovetsky (2004, p. 52):

O neologismo pós-moderno tinha um mérito: salientar uma mudança de direção, uma reorganização em profundidade do modo de funcionamento social e cultural das sociedades democráticas avançadas. Rápida expansão do consumo e

1 Tradução para o espanhol: La Posmodernidad, Barcelona: 1985, 5a ed. em 2002 (é a que utilizo como fonte das citações aqui presentes). 
da comunicação de massa; enfraquecimento das normas autoritárias e disciplinares; surto de individualização; consagração do hedonismo e do psicologismo; perda da fé no futuro revolucionário; descontentamento com as paixões políticas e as militâncias - era mesmo preciso dar um nome à enorme transformação que se desenrolava no placo das sociedades abastadas, livres do peso das grandes utopias futuristas da primeira modernidade.

Ao mesmo tempo, porém, a expressão pós-moderno era ambígua, desajeitada, para não dizer vaga. Isso porque era evidentemente uma modernidade de novo gênero que tomava corpo, e não uma simples superação daquela anterior. Donde as reticências legítimas que se manifestaram a respeito do prefixo pós. E acrescente-se isto: há vinte anos, o conceito de pós-moderno dava oxigênio, sugeria o novo, uma bifurcação maior; hoje, entretanto, está um tanto desusado. O ciclo pós-moderno se deu sob o signo da descompressão cool do social; agora, porém, temos a sensação de que os tempos voltam a endurecer-se, cobertos que estão de nuvens escuras. Tendo-se vivido um breve momento de redução das pressões e imposições sociais, eis que elas reaparecem em primeiro plano, nem que seja com novos traços. No momento em que triunfam a tecnologia e a genética, a globalização liberal e os direitos humanos, o rótulo pós-moderno já ganhou rugas, tendo esgotado sua capacidade de exprimir o mundo que anuncia.

Peço desculpas pela longa citação; no entanto, ela pareceu-me necessária, na medida em que faz o inventário do problema, afirmando que a expressão pós-modernidade teria atendido a certos objetivos, porém, encontrando-se já esgotada. Contra a noção de pós-modernidade, ou para além dela, na medida em que nunca teve condições de expressar um campo, Lipovetsky (2004, p. 53) propõe as expressões hipermoderno, hipermodernidade. Vejamos seu argumento:

O pós de pós-moderno ainda dirigia o olhar para um passado que se decretara morto; fazia pensar numa extinção sem determinar o que nos tornávamos, como se se tratasse de preservar uma liberdade nova, conquistada no rastro da dissolução dos enquadramentos sociais, políticos e ideológicos. Donde seu sucesso. Essa época terminou. Hipercapitalismo, hiperclasse, hiperpotência, hiperterrorismo, hiperindividualismo, hipermercado, hipertexto - o que mais não é hiper? O que mais não expõe uma modernidade elevada à potência superlativa? 
Ao clima de epílogo segue-se uma sensação de fuga para adiante, de modernização desenfreada, feita de mercantilização proliferativa, de desregulamentação econômica, de ímpeto técnico-científico, cujos efeitos são tão carregados de perigos quanto de promessas. Tudo foi muito rápido: a coruja de Minerva anunciava o nascimento do pós-moderno no momento mesmo em que se esboçava a hipermodernização do mundo.

Longe de decretar-se o óbito da modernidade, assiste-se a seu remate, concretizando-se no liberalismo globalizado, na mercantilização quase generalizada dos modos de vida, na exploração da razão instrumental até a 'morte' desta, numa individualização galopante.

Assim, Lipovetsky, que outrora foi um dos defensores da força explicativa do pós-moderno, afirmando a superação da modernidade, revê suas teses, encontrando, de certa forma, a posição defendida por Jürgen Habermas em O Discurso Filosófico da Modernidade, do qual essa é um projeto inacabado e que, não tendo sido completada, ainda não pode ser superada. Um ponto a ser assinalado, posto que mais adiante enfrentarei a abordagem política da questão: Lipovetsky passa de uma postura politicamente otimista, de ver no pós-modernismo uma força de renovação, de transformação, para uma posição pessimista, que vê no hipermodernismo o remate da modernidade naquilo que ela tem de mais reacionário e conservador: a mercantilização da vida, a globalização do liberalismo, a exploração da instrumentalização da razão até as últimas conseqüências.

Mas penso que tampouco as saídas propostas por Lipovetsky ou por Habermas resolvem o problema; no entanto, a noção de hipermodernidade acrescenta uma perspectiva interessante: a da "elasticidade" do projeto moderno. Retomo essa idéia que Deleuze e Guattari (1976) desenvolveram em O Anti-Édipo, quando mostram que o capitalismo é capaz de se metamorfosear. Quanto mais nos aproximamos de seus limites históricos, o que poderia significar uma crise e sua superação, os limites são alargados, elasticamente sendo colocados mais além. O capitalismo escapa e nos escapa; e, assim, permanece, embora não seja sempre o mesmo. Não será algo análogo ao que temos assistido nos debates em relação à modernidade e sua superação? As novas feições, 
talvez apressadamente demais denominadas de pós-modernidade, não serão nada mais do que as metamorfoses do projeto moderno, que assume novas feições, na medida em que suas realizações não nos satisfazem?

Colocando de uma outra maneira: não estaríamos condenados a viver uma "eterna modernidade", como que presos a um infinito crepúsculo, que nunca vê a noite cair, mas que também não recupera $\mathrm{o}$ brilho do meio-dia?

\section{Epistemologia: entre duas possibilidades para o conhecimento}

Deixando de lado essa discussão, que me parece não termos condições de esgotar ou de resolver, penso que para buscarmos as repercussões dessa tensão modernidade/pós-modernidade para o campo educacional, em especial para a pesquisa e a intervenção nesse campo, precisamos recuperar ao menos dois aspectos do projeto moderno: o epistemológico e o político.

No aspecto epistemológico, sabemos que o projeto moderno constituiu-se em torno da construção de um método "universal" para a produção do conhecimento. Em termos filosóficos, essa busca se inicia com Descartes e com a defesa da universalização do método matemático e termina (se é que terminou...) com Husserl e a proposta do método fenomenológico, manifestamente querendo superar os problemas do cartesianismo, que o impediram de lograr êxito em seu intento, buscando fazer da filosofia uma ciência de rigor.

Nesse contexto, assistimos à emergência e à consolidação da lógica disciplinar, implicando um determinado modelo de produção dos saberes e uma certa lógica da pesquisa. Parece-me que um dos pontos centrais de tal lógica disciplinar é a busca, a um só tempo, de uma objetividade e de uma universalidade do conhecimento, para que o mesmo possa ser reconhecido como válido e verdadeiro. A produção do conhecimento na modernidade foi marcada por esses princípios e a pesquisa em educação não pôde ficar alheia a eles.

Foucault (1999, p. 214-216) localiza no século XVIII o processo político levado a cabo pelo Estado de disciplinamento dos saberes. A partir de dois exemplos, o do saber técnico/tecnológico e o do saber médico, 
evidencia a espécie de "luta entre saberes" que ocorreu no "submundo das Luzes". Por trás do processo histórico que nos é apresentado como tendo sido a luta entre o conhecimento e a ignorância, o filósofo faz emergir um conflito entre uma multiplicidade de saberes que se opunham entre si. E, para organizar esse campo, o Estado exerceu seu "poder disciplinador", que operou através de quatro procedimentos básicos: desqualificação/seleção; normalização; hierarquização; centralização piramidal.

Num primeiro movimento, esses saberes foram selecionados, através de um processo de desqualificação e eliminação de "pequenos saberes inúteis e irredutíveis, economicamente dispendiosos" (FOUCAULT, 1999, p. 215). Em seguida, passou-se à sua normalização, isto é, fazendo-os comunicar-se entre si, tornando-os intercambiáveis. O terceiro movimento é o da classificação hierárquica desses saberes, dos mais específicos e materiais, que são subordinados aos mais formais e mais gerais. Por fim, a centralização piramidal do conjunto dos saberes, que permitiu seu controle, sua seleção, sua transmissão, sua organização geral. E conclui Foucault (1999, p. 217-218):

São essas quatro operações que podemos ver em andamento num estudo um pouco detalhado daquilo que é denominado o poder disciplinar. O século XVIII foi o século do disciplinamento dos saberes, ou seja, da organização interna de cada saber como uma disciplina tendo, em seu campo próprio, a um só tempo critérios de seleção que permitem descartar o falso saber, o não-saber, formas de normalização e de homogeneização dos conteúdos, formas de hierarquização e, enfim, uma organização interna de centralização desses saberes em torno de um tipo de axiomatização de fato. Logo, organização de cada saber como disciplina e, de outro lado, escalonamento desses saberes assim disciplinados do interior, sua intercomunicação, sua distribuição, sua hierarquização recíproca numa espécie de campo global ou de disciplina global a que chamam precisamente de $a$ "ciência". A ciência não existia antes do século XVIII. Existiam ciências, existiam saberes, existia, se vocês quiserem, a filosofia. A filosofia era justamente o sistema de organização, ou melhor, de comunicação, dos saberes uns em relação aos outros - é nesta medida que ela podia ter um papel efetivo, real, operacional, no interior do desenvolvimento dos saberes [...] A ciência, como domínio geral, como policiamento disciplinar dos saberes, tomou o lugar tanto 
da filosofia quanto da mathesis. E doravante ela vai formular problemas específicos ao policiamento disciplinar dos saberes: problemas de classificação, problemas de hierarquização, problemas de vizinhança, etc.

Todo esse amplo processo de disciplinarização dos saberes terá, segundo Foucault, uma série de conseqüências. Entre elas, destaco a conformação do perfil moderno da Universidade como instituição classificadora e legitimadora dos saberes; a constituição da assim chamada "comunidade científica", operadora e gerenciadora do consenso acadêmico; por fim, uma mudança na forma do dogmatismo, que se desloca da ortodoxia (isto é, a "censura dos enunciados") para uma espécie de "ortologia" (que seria a "disciplina da enunciação", a forma de controle que se exerce através da disciplina, tendo a ciência como poder regulador e não mais a filosofia).

Ainda está por ser feito um estudo específico sobre como os saberes educacionais e pedagógicos participaram desses jogos de conformação e disciplinamento dos saberes modernos. É inegável, porém, que sofreram diretamente esses efeitos.

Mas, do interior da própria lógica disciplinar, começamos, no final do século XIX, a perceber sintomas de seu esgotamento. Para citar apenas um caso, na Física, a ciência exata por natureza, por exemplo, começa-se a falar em indeterminação, incerteza, relatividade... A produção sobre isso já é imensa, e não retornarei a essas discussões.

Nesse movimento, no campo da filosofia destacou-se a vOz de Nietzsche, que fez a crítica ao uso da razão tomada como absoluta, procurando mostrar que o conhecimento é sobretudo vida, é encarnado, é ligado ao mundo, por mais que tentemos transformá-lo em formas puras e abstratas. O movimento de Nietzsche é justamente o de colocar em xeque os procedimentos de universalização e objetividade do conhecimento moderno, defendendo aquilo que depois seria chamado de "perspectivismo"2.

2 Sobre o perspectivismo de Nietzsche, ver os livros de António Marques, A Filosofia Perspectivista de Nietzsche e de Gilvan Fogel Conhecer é Criar - um ensaio a partir de F. Nietzssche, ambos publicados pela Discurso Editorial e Ed. Unijuí, na coleção Sendas e Veredas, organizada pelo Grupo de Estudos Nietzsche, da Universidade de São Paulo. 
Gianni Vattimo identifica a crítica de Nietzsche como uma crítica à noção de fundamento. Embora o filósofo italiano aponte o alemão como um "filósofo da pós-modernidade", afirmação que me parece um tanto quanto apressada, penso ser interessante sua argumentação:

Do ponto de vista de Nietzsche e Heidegger, que podemos considerar comum, não obstante as diferenças nada ligeiras, a modernidade pode caracterizar-se, de fato, por ser dominada pela idéia da história do pensamento como uma "iluminação" progressiva, que se desenvolve com base na apropriação e na reapropriação cada vez mais plena dos "fundamentos", que freqüentemente são pensados também como as "origens", de modo que as revoluções teóricas e práticas da história ocidental se apresentam e se legitimam na maioria das vezes como "recuperações", renascimentos, retornos. A noção de "superação", que tanta importância tem em toda a filosofia moderna, concebe o curso do pensamento como um desenvolvimento progressivo, em que o novo se identifica com o valor através da recuperação e da apropriação do fundamento-origem. Mas precisamente a noção de fundamento, e de pensamento como fundação e acesso ao fundamento, é radicalmente posta em discussão por Nietzsche e por Heidegger. Eles se acham assim, por um lado, na condição de terem de distanciar-se criticamente do pensamento ocidental enquanto pensamento do fundamento; de outro porém, não podem criticar esse pensamento em nome de uma outra fundação, mais verdadeira. É nisso que, a justo título, podem ser considerados os filósofos da pós-modernidade. O pós de pós-moderno indica, com efeito, uma despedida da modernidade, que, na medida em que quer fugir das suas lógicas de desenvolvimento, ou seja, sobretudo da idéia de "superação" crítica em direção a uma nova fundamentação, busca precisamente o que Nietzsche e Heidegger procuraram em sua peculiar relação "crítica" com o pensamento ocidental (VATTIMO, 1996, p. VI-VII).

No caso de Nietzsche, posto que não entraremos aqui no pensamento de Heidegger, a noção moderna de fundamento para o conhecimento é criticada e substituída não por um novo fundamento, mas justamente pela idéia de perspectiva, como veremos adiante. Já num texto de sua juventude, mais precisamente de 1873, intitulado Acerca da Verdade e da 
Mentira no Sentido Extramoral, o filósofo alemão coloca o conhecimento como uma invenção e a verdade como metáfora, com isso questionando a própria noção de fundamento e portanto a possibilidade de um conhecimento objetivo e universal. Começa demarcando a insignificância do homem no universo, num movimento oposto ao do humanismo moderno:

Num certo canto remoto do universo cintilante vertido em incontáveis sistemas solares havia uma vez um astro onde animais inteligentes inventaram o conhecimento. Foi o minuto mais soberbo e hipócrita da 'história mundial', mas foi apenas um minuto. Depois de a natureza ter respirado umas poucas vezes, o astro enregelou e os animais inteligentes tiveram de morrer. Assim, alguém poderia inventar uma fábula como esta e, no entanto, não ficaria suficientemente esclarecido quão lastimável, quão obscuro e fugidio, quão desprovido de finalidade e arbitrário se apresenta o intelecto bumano no interior da natureza. Eternidades houve em que ele não existia; quando ele tiver de novo desaparecido, nada se terá alterado. Pois para este intelecto não há outra missão que transcenda a vida bumana (NIETZSCHE, 1997, p. 215, grifo nosso).

E, mais adiante, apresenta a verdade como invenção, metáfora, ilusão:

Que é então a verdade? Um exército móvel de metáforas, de metonímias, de antropomorfismos, numa palavra, uma soma de relações humanas que foram poética e retoricamente intensificadas, transpostas e adornadas e que depois de um longo uso parecem a um povo fixas, canônicas e vinculativas: as verdades são ilusões que foram esquecidas enquanto tais, metáforas que foram gastas e que ficaram esvaziadas do seu sentido, moedas que perderam o seu cunho e que agora são consideradas não já como moedas, mas como metal (NIETZSCHE, 1997, P. 221, grifo nosso).

Como se pode ver, então, já nesse texto de juventude Nietzsche "filosofa com o martelo", mostrando que as verdades são como "ídolos

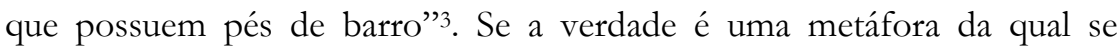

\footnotetext{
3 Estou parafraseando o próprio Nietzsche naquela que foi a última obra que escreveu,
} Crepúsculo dos Ídolos, de 1888. 
esqueceu o sentido, isso significa que não há fundamento para a verdade, por um lado, e, por outro, que as verdades não podem ser tomadas como fundamentos para o conhecimento ou para quaisquer outras coisas. As verdades são históricas, transitórias, fugidias... Nas suas obras posteriores, a crítica à modernidade e seu processo de construção de conhecimentos sempre baseados em fundamentos, com a pretensão de serem verdadeiros, objetivos, universais continua, ganhando novos contornos.

Vejamos brevemente algumas provocações de Nietzsche aos “homens de conhecimento". Em A Gaia Ciência, obra de 1882, podemos ler:

\begin{abstract}
Devido a três erros. Durante os últimos séculos promoveu-se o desenvolvimento da ciência, em parte porque era por meio da ciência que se esperava compreender melhor a bondade e sabedoria de Deus - motivo principal na alma dos ingleses notáveis, como Newton -, em parte porque se acreditava na utilidade absoluta do conhecimento, designadamente, na mais estreita ligação entre a moral, a ciência e a felicidade - motivo principal na alma dos franceses notáveis, como Voltaire -, em parte porque se pretendia possuir e amar na ciência algo de altruísta, inofensivo, auto-suficiente e verdadeiramente inocente, no qual os impulsos maus do homem não desempenhariam nenhum papel - motivo principal na alma de Espinosa, que se sentia divino enquanto sujeito cognoscente, portanto, devido a três erros (NIETZSCHE, 1998a, p. 51) ${ }^{4}$.
\end{abstract}

Em sua visão, foram três os equívocos básicos que levaram ao desenvolvimento da ciência moderna: o desejo de conhecer a "mente" de Deus, através da natureza; um desejo de verdade aliado a uma crença moral de que conhecer mais significa ser melhor e mais feliz; e, por fim, uma crença na bondade intrínseca do homem, como se todo saber só pudesse ter bons efeitos, nunca redundando em exploração, domínio, morte. Mas o que assistimos, ao longo desses últimos séculos, foi justamente o contrário disso tudo. $\mathrm{E}$ isso porque as pretensões originais da ciência não teriam como se realizar: primeiro, mesmo que possamos conhecer a natureza, a premissa de que ela exprima a "mente de Deus" não é comprovável; em

\footnotetext{
${ }^{4}$ Cito aqui o $\int 37$.
} 
segundo lugar, mais conhecimento não significa mais felicidade, isto é, não é possível estabelecer uma relação direta entre conhecimento e ética; por fim, a ciência não é neutra, nem neutros são os seres humanos de posse dos conhecimentos, tornando impossível a afirmação de um uso "moral" da tecnologia. Com isso, parece-me que Nietzsche antecipa bastante as críticas que no século XX seriam dirigidas ao positivismo, na medida em que o faz no momento mesmo de hegemonização dele.

Em outro aforismo desse livro enigmático, Nietzsche afirma que o que importa ao conhecimento não é exatamente o quão verdadeiro ele se apresenta, mas sua antiguidade, isto é, o seu tempo de sedimentação, de "incorporação" pelos homens, tendo em vista que vai se encarnando nas vidas dos indivíduos. E, conforme esses conhecimentos se incorporam, passam a ser parte de uma verdadeira luta pelo poder, lembrando os processos de disciplinamento evidenciados por Foucault (1999, p.126-127).5

\footnotetext{
Portanto, a força dos conhecimentos não reside no seu grau de verdade, mas sim na sua idade, no seu grau de incorporação, no seu carácter como condição de vida [...] Pouco a pouco foi-se enchendo o cérebro humano destes juízos e dessas convicções e, nesse novelo, produziu-se a fermentação, a luta e a ânsia pelo poder. A utilidade e o prazer não foram os únicos a tomar partido na luta pelas "verdades", mas igualmente todo o gênero de impulsos; a luta intelectual tornouse ocupação, atração, profissão, dever, dignidade; o ato de conhecer e a aspiração de atingir o verdadeiro passaram por fim a integrar-se, como necessidades, nas outras necessidades. A partir daí, não apenas a fé e a convicção, mas também o exame, a negação, a desconfiança, a contradição tornaram-se um poder.
}

A esse respeito, seria interessante voltarmos também a Paul Feyerabend e seu "anarquismo epistemológico" de Contra o Método, obra esquecida fora dos círculos epistemológicos. Encontramos um grande paralelismo entre as idéias de Nietzsche e as desse que foi um dos grandes epistemólogos do século XX. Destaco um trecho da introdução dessa bela obra, em que isso fica claro:

${ }^{5}$ Agora a citação é de trechos do $\ 110$. 
A educação científica, tal como hoje a conhecemos, tem precisamente esse objetivo. Simplifica a ciência, simplificando seus elementos: antes de tudo, define-se um campo de pesquisa; esse campo é desligado do resto da História (a Física, por exemplo, é separada da Metafísica e da Teologia) e recebe uma 'lógica' própria. Um treinamento completo, nesse tipo de 'lógica', leva ao condicionamento dos que trabalham no campo delimitado; isso torna mais uniformes as ações de tais pessoas, ao mesmo tempo em que congela grandes porções do processo histórico. 'Fatos' estáveis surgem e se mantêm, a despeito das vicissitudes da História. Parte essencial do treinamento, que faz com que fatos dessa espécie apareçam, consiste na tentativa de inibir intuições que possam implicar a confusão de fronteiras. A religião da pessoa, por exemplo, ou sua metafísica ou seu senso de humor (seu senso de humor natural e não a jocosidade postiça e sempre desagradável que encontramos em profissões especializadas) devem manter-se inteiramente à parte de sua atividade científica. Sua imaginação vê-se restringida e até sua linguagem deixa de ser própria. E isso penetra a natureza dos 'fatos' científicos, que passam a ser vistos como independentes de opinião, de crença ou de formação cultural.

É possível, assim, criar uma tradição que se mantém uma, ou intacta, graças à observância de regras estritas, e que, até certo ponto, alcança êxito. Mas será desejável dar apoio a essa tradição, a despeito de tudo mais? Devemos concederlhe direitos exclusivos de manipular o conhecimento, de tal modo que quaisquer resultados obtidos por outros métodos sejam, de imediato, ignorados? (FEYERABEND, 1989, p. 21).

Soa-me inequívoco o paralelismo da crítica de Feyerabend com a crítica de Nietzsche, embora separadas por praticamente um século. Desliga-se a ciência, o conhecimento da história, fazendo-se com que se esqueçam suas origens, dando-lhe então uma completa autonomia, como se tivesse uma "lógica" própria. Outro destaque para o trecho citado é sua proximidade com as teses apresentadas por Foucault, de que no século XVIII a ciência ganha o status de "polícia disciplinar dos saberes", na medida em que normaliza a produção de conhecimento e gerencia esse 
processo, definindo o que pode e o que não pode ser pesquisado, o que pode e o que não pode ser dito ou ensinado. ${ }^{6}$

Mas fechemos esse parêntese e voltemos a Nietzsche. Será em Genealogia da Moral, livro de 1887, portanto já da fase final de sua produção, que encontraremos o lançamento do desafio de um "conhecimento perspectivo". Nessa obra, Nietzsche afirmou que os seres humanos, enquanto produtores de saberes, devem agir levando em conta a diversidade de perspectivas, tomando-a como positiva e não como um problema para a objetividade que leva à verdade universal. Sigamos seu raciocínio:

Devemos afinal, como homens do conhecimento, ser gratos a tais resolutas inversões das perspectivas e valorações costumeiras, com que o espírito, de modo aparentemente sacrílego e inútil, enfureceu-se consigo mesmo por tanto tempo: ver assim diferente, querer ver assim diferente, é uma grande disciplina e preparação do intelecto para sua futura "objetividade" - a qual não é entendida como "observação desinteressada" (um absurdo sem sentido), mas como a faculdade de ter seu pró e seu contra sob controle e deles poder dispor: de modo a saber utilizar em prol do conhecimento a diversidade de perspectivas e interpretações afetivas. (NIETZSCHE, 1998b, p. 108-109). ${ }^{7}$

Fazendo a crítica do suposto desinteresse na observação, do mito da objetividade, Nietzsche chama a atenção dos filósofos, dos "homens de conhecimento" para a fábula do "sujeito universal e isento do conhecimento":

De agora em diante, senhores filósofos, guardemo-nos bem contra a antiga, perigosa fábula conceitual que estabelece um "puro sujeito do conhecimento, isento de vontade, alheio à dor e ao tempo", guardemo-nos dos tentáculos de conceitos contraditórios como "razão pura", "espiritualidade absoluta",

\footnotetext{
${ }^{6}$ A primeira publicação em língua inglesa do livro de Feyerabend data de 1975; o curso de Foucault, publicado com o título Em Defesa da Sociedade, por sua vez, aconteceu entre janeiro e março de 1976. Embora o filósofo francês não cite ali o epistemólogo, não seria de se estranhar que ele tivesse nele se inspirado.

$73^{\mathrm{a}}$ Dissertação, $\int 12$.
} 


\begin{abstract}
"conhecimento em si"; - tudo isso pede que se imagine um olho que não pode absolutamente ser imaginado, um olho voltado para nenhuma direção, no qual as forças ativas e interpretativas, as que fazem com que ver seja ver-algo, devem estar imobilizadas, ausentes; exige-se do olho, portanto, algo absurdo e sem sentido (NIETZSCHE, 1998b, p. 109).
\end{abstract}

Com essa crítica dirigida a cânones do pensamento moderno, como Descartes, Kant (quando fala em "razão pura") ou Hegel (quando fala em "espiritualidade absoluta" e "conhecimento em si"), denunciando que o fundamento, a objetividade, a universalidade não são mais do que fábulas, Nietzsche lança seu apelo pelo conhecimento perspectivo:

\footnotetext{
Existe apenas uma visão perspectiva, apenas um "conhecer" perspectivo; e quanto mais afetos permitirmos falar sobre uma coisa, quanto mais olhos, diferentes olhos, soubermos utilizar para essa coisa, tanto mais completo será nosso "conceito" dela, nossa "objetividade". Mas eliminar a vontade inteiramente, suspender os afetos, todos sem exceção, supondo que o conseguíssemos: como? - não seria castrar o intelecto?... (NIETZSCHE, 1998b, p. 109).
}

O desafio nietzschiano aos "homens de conhecimento" é o desafio da multiplicidade. Quando em nome de uma suposta objetividade abrimos mão dos afetos de cada um dos sujeitos humanos encarnados que conhecem, nada mais fazemos do que "castrar" o intelecto. Para além de qualquer objetividade, para além de qualquer "vontade de verdade", é a multiplicidade de olhares, a multiplicidade de afetos sobre um mesmo objeto (isto é, um perspectivismo) que pode possibilitar-nos um conhecimento mais completo desse objeto.

Se tomarmos a sério o desafio de Nietzsche, assim como fizeram diversos filósofos contemporâneos, entre os quais destaco Foucault, Deleuze e Guattari, Derrida, por exemplo, impõe-se uma outra atitude frente ao processo de produção de saberes e frente ao próprio processo de pesquisa (no nosso caso, em educação). Uma atitude que implica um outro tipo de trânsito por entre os campos disciplinares, que já não dão conta da multiplicidade do mundo, que insiste em escapar por entre os vãos das grades disciplinares. $\mathrm{Na}$ mesma medida, aquela ciência como "polícia 
disciplinar dos saberes", apontada por Foucault, também já não consegue controlar esses processos de escape, de fuga, de proliferação de saberes.

Penso que essa atitude pode ser identificada com aquilo que, na companhia desses filósofos, chamo de transversalidade ${ }^{8}$, que implica uma postura não hierárquica (tanto vertical quanto horizontal), não prédefinida, não universalizante. Nessa direção, Deleuze e Guattari desenvolveram, em Mil Platôs, uma discussão em torno daquilo que chamaram de uma "ciência régia" (ou, ainda, ciência maior) e de uma "ciência nômade" (ou, ainda, ciência menor) ${ }^{9}$. Enquanto o primeiro tipo é financiado e gerido pelo Estado, funcionando como aquela "polícia disciplinar" da qual falava Foucault, o segundo tipo "vaza" por entre as grades, escapa, resiste, subverte. É bem verdade, porém, e Deleuze e Guattari o mostram, que não é raro a ciência nômade ou menor ser capturada pela máquina de Estado, tornando-se ela própria ciência régia, trocando de papel; mas também é certo que há aquelas que nunca se deixam capturar.

Após esse longo desfile de idéias e de considerações críticas em relação ao conhecimento e sua produção na modernidade, penso estar em condições de fazer algumas afirmações mais conclusivas. Parece-me que vivemos hoje, na pesquisa em educação no Brasil, a tensão entre um estilo "clássico" de pesquisa, articulado com uma perspectiva positiva, disciplinar, universalizante, e um estilo "transversal", que investe na errância da curiosidade, apostando na emergência de possibilidades distintas, articulado com uma lógica da diferença, não universalizante. Para falarmos junto com Deleuze e Guattari, poderíamos identificar o primeiro estilo como uma espécie de "pesquisa régia ou maior", feita de acordo com os cânones,

8 Várias foram as teorizações em torno do conceito de transversalidade como uma abordagem não disciplinar e não hierárquica aos campos de saberes empreendidas pelos filósofos citados acima. No entanto, talvez tenha sido Félix Guattari quem lhe deu uma forma conceitual um pouco mais trabalhada, curiosamente num ensaio escrito ainda no início da década de 1960, em que se utiliza desse conceito para pensar a prática da analítica institucional, então ainda em constituição. Guattari propõe substituir o conceito psicanalítico de "transferência", que ele considera hierárquico e normalizador, pelo de "transversalidade", que seria não hierárquico e mais operativo. Esse ensaio foi publicado em português incluído na coletânea Revolução Molecular, organizada por Suely Rolnik.

9 Em Mil Platôs, ver especialmente o ensaio intitulado Tratado de Nomadologia: a máquina de guerra. $\mathrm{Na}$ edição brasileira dessa obra pela Editora 34, publicada em cinco volumes, esse ensaio encontra-se no volume 5 . 
respeitando os paradigmas definidos pela máquina estatal e pelas agências de fomento, utilizando-se de métodos bem definidos e chegando a conclusões previsíveis e não perturbadoras (embora muitas vezes de grande importância e impacto). Já o segundo estilo poderíamos identificar com uma "pesquisa nômade ou menor", que escapa, vaza, passa pelas grades disciplinares, gerando saberes menores, distintos, inusitados. Claro que esse segundo estilo pode ser capturado; algumas vezes ele já é produzido movido por um desejo de captura, querendo vir a fazer parte da máquina de Estado, a definir políticas públicas, a fazer jus a gordas fatias de financiamento. Mas em outras vezes ele é produzido mesmo como desejo de fuga, ciente do risco de perecer, de ser apagado, negado, vilipendiado.

Trata-se da tensão entre um paradigma moderno e um suposto paradigma "pós-moderno"? Parece-me difícil dizer. Parece-me mais o conflito entre dois modelos de produção de conhecimento, entre duas imagens do pensamento ${ }^{10}$, para usar o conceito de Deleuze, de resto já muito antigas ambas, posto que chegam a nós da antiguidade grega e das origens da filosofia (não é por acaso que Nietzsche convida para uma volta aos gregos, para uma volta ao agonismo pré-platônico).

Explico, ao menos em parte. Penso que essas duas imagens do pensamento, uma ciência régia (ou uma filosofia régia, ou um saber régio, ou, ainda, uma educação régia), maior, e uma ciência nômade (ou uma filosofia nômade, ou um saber nômade, ou, ainda, uma educação nômade), menor, estão em tensão desde a antiguidade. A ciência régia tem sido, evidentemente, hegemônica, e isso não se deu apenas na chamada modernidade; mas isso não faz da ciência nômade algo novo, pósmoderno. Penso que uma análise histórica dos processos humanos de produção dos saberes mostra-nos que, nos interstícios dos saberes "oficiais", são sempre produzidos saberes múltiplos, que escapam ao processo, que não se tornam hegemônicos. Às vezes, esses saberes menores são deliberadamente perseguidos, apagados, quando não podem ser capturados pela teia "oficial". Noutras vezes, são deixados ao léu, para que pereçam por si mesmos. A história da ciência, a história da filosofia, a

10 Utilizo-me aqui do conceito de "imagem do pensamento" inspirado por Gilles Deleuze de Diferença e Repetição. 
história do pensamento, de forma, geral, é sempre a história dos saberes hegemônicos; mas isso não significa, de forma alguma, que sejam únicos ${ }^{11}$.

Longe de ser uma espécie de "sinal dos tempos", pois, parece-me que a tensão que vivemos hoje, e que tem sido evidenciada como um embate entre uma concepção moderna e uma concepção pós-moderna de mundo, de conhecimento, deve-se apenas a uma potencialização de um antagonismo antigo e que esteve sempre aí presente, mas sem o destaque que alcança em nossos dias.

\section{Política: conservar, reformar ou transformar?}

O segundo aspecto do projeto moderno que me parece importante para esse debate é o político. Não terei condições de desenvolvê-lo de forma tão extensa quanto o epistemológico, mas quero ao menos delinear seus contornos.

$\mathrm{Na}$ modernidade, a escola em particular e os processos educativos em geral também articularam-se em torno de um projeto. A educação moderna construiu-se como um projeto de emancipação do homem, articulada com projetos de emancipação nos âmbitos do social, do econômico, do cultural etc. Penso que a filosofia moderna foi animada por esse "desejo de emancipação": emancipação do conhecimento do jugo da fé pelo exercício da razão, articulado por um método; emancipação do poder soberano pelo livre exercício do poder pelo conjunto dos cidadãos, no contexto de uma sociedade democrática; emancipação do homem em relação à natureza pelo uso tecnológico permitido pelos conhecimentos científicos; emancipação da ignorância pela universalização do acesso aos processos educativos, e assim por diante...

E se houve os projetos emancipatórios da conservação (por mais paradoxal que isso possa parecer), como o projeto burguês da universalização da instrução pública, também houve os projetos emancipatórios de busca de superação da ordem instituída.

\footnotetext{
11 Remeto novamente o leitor a dois textos já citados aqui, em que esse tipo de abordagem é claro: a aula de Em Defesa da Sociedade em que Foucault analisa o disciplinamento dos saberes no século XVIII e o Tratado de Nomadologia, de Deleuze e Guattari.
} 
Mas, conservação ou superação, ambos os projetos foram construídos como propostas universais e universalizantes. O projeto liberal burguês moderno foi construído como um processo de emancipação da ordem feudal, apresentado de modo universal, isto é, para todos (embora cada classe tivesse seu próprio papel nesse processo...). Também os processos emancipatórios socialistas, que desejaram libertar os seres humanos da sociedade de classes, da exploração, foram construídos de maneira universalizante: uma nova sociedade, uma sociedade de iguais, para todos. Em outras palavras, esses projetos pensaram e pensaram-se no contexto de uma política da transcendência, que marcou a modernidade.

$\mathrm{O}$ que vemos emergir na segunda metade do século $\mathrm{XX}$, com especial ênfase nos processos revolucionários de 1968, foi um outro tipo de ação política, já não tomado em sentido universal, mas, numa perspectiva imanente ${ }^{12}$, pensado como ação local, como uma espécie de "micropolítica". Em um outro ensaio de Mil Platôs, intitulado Micropolítica e Segmentaridade, Deleuze e Guattari afirmam que toda sociedade humana é segmentarizada, o que faz com que as relações políticas sejam sempre localizadas. Se há ações políticas mais gerais, globais, é porque elas assentam-se sobre essas relações localizadas.

O sistema político moderno é um todo global, unificado e unificante, mas porque implica um conjunto de subsistemas justapostos, imbricados, ordenador, de modo que a análise das decisões revela toda espécie de compartimentações e de processos parciais que não se prolongam uns nos outros sem defasagens ou deslocamentos (DELEUZE; GUATTARI, 1996, p. 85).

Sem entrar nos detalhes da interessante análise feita pelos filósofos franceses, destaco então que eles chamam nossa atenção para esses dois campos, essas duas esferas da política: uma mais geral, mais ampla, mais abrangente, relativa à esfera dos Estados; e outra, mais localizada, mais restrita, mais circunscrita, relativa à esfera dos indivíduos em seu cotidiano. Equívoco seria imaginar que essas duas esferas são excludentes: uma só existe pela outra. A perspectiva apontada por eles é a da coexistência e

\footnotetext{
12 Sobre a noção de imanência na política, ver a obra de analítica do presente escrita por Antonio Negri e Michael Hardt, Império.
} 
mútua interferência de uma macropolítica ("grande" política; política “maior"; política "molar”) e uma micropolítica ("pequena” política; política "menor"; política "molecular").

Toda sociedade e todo indivíduo são, pois, atravessados por duas segmentaridades ao mesmo tempo: uma molar e outra molecular. Se elas se distinguem, é porque não têm os mesmos termos, nem as mesmas correlações, nem a mesma natureza, nem o mesmo tipo de multiplicidade. Mas, se são inseparáveis, é porque coexistem, passam uma para a outra, segundo diferentes figuras, como nos primitivos ou em nós - mas sempre uma pressupondo a outra. Em suma, tudo é político, mas toda política é ao mesmo tempo macropolitica e micropolítica (DELEUZE; GUATTARI, 1996, p. 90).

A questão que se coloca para nós, portanto, é a escolha de onde colocar o foco. Os grandes projetos emancipadores da modernidade focaram - e continuam focando - ações molares, na macropolítica; as lutas sociais da segunda metade do século XX, por sua vez, começaram a focar as ações moleculares, a micropolítica, uma espécie de política do cotidiano. Como mostraram Deleuze e Guattari, porém, isso não é nada novo; desde as sociedades primitivas se investe tanto em micropolítica quanto em macropolítica. Se na modernidade as ações molares foram hegemônicas, não significa que as ações moleculares desapareceram; e se hoje há grupos que reivindicam uma hegemonização das ações moleculares, isso certamente não significará o desaparecimento da macropolítica.

A tensão que vivemos hoje, pois, é entre os projetos universalizantes e as ações perspectivas, para deslocar o termo de Nietzsche para esse âmbito. Mas também aqui temos ações de conservação e ações de transformação. Da mesma maneira que podemos investir numa macropolítica revolucionária, certamente há investimentos micropolíticos reacionários: o fascismo talvez seja o principal exemplo ${ }^{13}$. E o contrário não é menos verdadeiro...

13 Remeto o leitor uma vez mais para o ensaio Micropolitica e Segmentaridade, já citado aqui. Deleuze e Guattari fazem uma análise do fenômeno político do fascismo, mostrando que sua força e abrangência deve-se justamente ao fato de seu componente micropolítico, seu investimento ao nível do desejo. Se no século XX ele pode fazer-se "fascismo de Estado", ganhando o plano molar, isso deveu-se a seu caráter molecular. 
Voltando ao debate em torno do pós-modernismo, retomo Foster (2002), cujo texto já citei e que foi feito como introdução a uma coletânea de artigos (do início da década de 1980) sobre a estética na cultura pósmoderna, que apresenta uma tese interessante, pelo seu aspecto político: haveria duas espécies de pós-modernismos. Uma espécie que faz a crítica da modernidade desde uma perspectiva reacionária, na medida em que defende a manutenção do estado de coisas; e uma outra espécie, de resistência, que toma a crítica da modernidade como uma forma de oporse à manutenção do estado de coisas. Duas posturas políticas antagônicas, duas maneiras distintas de vivenciar e analisar o mesmo fenômeno. Vejamos sua caracterização:

Na política cultural existe hoje uma oposição básica entre um pós-modernismo que se propõe [a] desconstruir o modernismo e opor-se ao status quo e um pósmodernismo que repudia o primeiro e elogia o segundo: um pós-modernismo de resistência e outro de reação (FOSTER, 2002, p. 11, tradução nossa).

O pós-modernismo de reação está articulado com uma espécie de neoconservadorismo, dada a sua preocupação em resgatar valores de origem, questionados pelo modernismo, que quer superá-los:

O pós-modernismo de reação é muito melhor conhecido: ainda que não seja monolítico, é singularizado por seu repúdio ao modernismo. Este repúdio, cujos porta-vozes mais ruidosos sejam talvez os neoconservadores, mas que encontrou eco por todas as partes, é estratégico: como argumenta Habermas de modo convincente, os neoconservadores rompem o vínculo do cultural e do social, e em seguida culpam as práticas culturais (modernismo) pelos males sociais (modernização). Com esta confusão de causa e efeito, a cultura "adversária" é denunciada, inclusive enquanto se afirma o status quo econômico e político... propõe-se, com efeito, uma nova cultura "afirmativa” (FOSTER, 2002, p. 11-12, tradução nossa).

Por outro lado, um pós-modernismo de resistência critica o modernismo, mas também o status quo; em lugar de uma volta às origens, faz a sua crítica: 
Vemos, pois, que surge um pós-modernismo de resistência como uma contraprática, não apenas da cultura oficial do modernismo, mas também da "falsa normatividade" de um pós-modernismo reacionário. Em oposição (mas não somente em oposição), um pós-modernismo resistente se interessa por uma desconstrução crítica da tradição, não por um pastiche instrumental de formas pop ou pseudo-históricas, uma crítica das origens, não um retorno a elas. Em uma palavra, trata-se de questionar mais do que de explorar códigos culturais, explorá-los mais do que ocultar filiações sociais e políticas (FOSTER, 2002, p. 12, tradução nossa).

A tese de Foster parece avançar um pouco no debate (embora se circunscreva ainda à disjunção modernidade/pós-modernidade), por colocar ênfase no aspecto político da questão. De fato, o que importa mais é saber se as práticas culturais (educacionais, no nosso caso específico) estão voltadas para a manutenção das coisas ou para sua transformação. $\mathrm{O}$ debate sobre a tensão modernidade/pós-modernidade não pode obscurecer nossa percepção para esse fato.

Tentando fechar um pouco a questão, eu diria que também no aspecto político o que vemos hoje é a tensão entre duas imagens do pensamento antigas, antiqüíssimas. Tendências à universalização, a ênfase no macropolítico, tanto em sentido reacionário quanto em sentido revolucionário, existem desde os primórdios da civilização. Do mesmo modo, tendências micropolíticas, seja em sentido revolucionário, seja em sentido reacionário, conservador, coexistiram com elas desde a mesma época. Transformar isso tudo em dois grandes paradigmas políticos antagônicos, identificando um deles com a conservação e o outro com a transformação, não passa de um reducionismo, que em nada pode nos auxiliar.

O problema que se abre para nós é saber identificar cada uma dessas imagens do pensamento em seu aspecto político, clareando seus objetivos e suas filiações, de modo a permitir uma opção clara, uma aposta na produção de uma investigação, de um conhecimento que esteja identificado com manutenção ou transformação, seja ele baseado numa 
política da transcendência (seguindo a hegemonia moderna) ou numa política da imanência (articulado com perspectivas mais recentes).

\section{Concluindo...}

Bem sei que este artigo mais abriu questões do que as resolveu; penso ser essa, porém, a nossa possibilidade neste momento histórico. Procurei trazer elementos para o debate sobre a tensão modernidade/pósmodernidade de modo a deslocá-lo dessa decisão que me parece tão pouco operativa: optar por um lado ou por outro.

Procurei desmontar a lógica dos argumentos em torno do assim chamado "pós-modernismo", na medida em que ele parece não ter a força e a intensidade do conceito, em sentido filosófico. Porém, não podemos nos fazer cegos às questões que ele nos coloca.

A meu ver, o desafio que se impõe a nós consiste em viver essas tensões de forma criativa e produtiva. Investigar a fundo o projeto moderno, tanto em seus aspectos epistemológicos quanto em seus aspectos políticos; investigar a fundo também as propostas contemporâneas, identificadas ou não como pós-modernismo, também em seus aspectos políticos e epistemológicos. E nessas investigações apreender os caminhos e possibilidades que se abrem para um saber compromissado, comprometido, articulado em torno de um projeto claramente exposto.

Em suma, agir de modo que a tensão não nos impeça de pensar; que a "vitória" de uma das posições não nos impeça de pensar. Que o pensamento e a ação criativa e produtiva sigam possíveis em educação. Esse parece ser o único sentido desse debate.

\section{Referências}

DELEUZE, Gilles. Diferença e Repetição. Trad. de Luiz Orlandi e Roberto Machado. Lisboa: Relógio D’Água, 2000.

DELEUZE, Gilles; GUATTARI, Félix. Micropolítica e Segmentaridade. In: DELEUZE, Gilles; GUATTARI, Félix. Mil Platôs. Trad. de Aurélio Guerra Neto, Ana Lúcia de Oliveira, Lúcia Cláudia Leão e Suely Rolnik. São Paulo: Ed. 34, 1996. v. 3. 
DELEUZE, Gilles; GUATTARI, Félix. Mille Plateaux: capitalisme et schizophrènie. Paris: Les Editions de Minuit, 1980.

O Anti-Édipo - capitalismo e esquizofrenia. Trad. de Georges Lamazière. Rio de Janeiro: Imago, 1976.

DICIONÁRIO eletrônico Houaiss da Língua Portuguesa. Versão 1.0. Rio de Janeiro: Objetiva, 2001.

FEYERABEND, Paul. Contra o Método. Trad. de Octanny S. da Mota e Leonidas Hegenberg. 3. ed. Rio de Janeiro: Francisco Alves, 1989.

FOGEL, Gilvan. Conbecer é Criar - um ensaio a partir de F. Nietz̧sche. São Paulo: Discurso Editorial; Ijuí: GEN/Ed. UNIJUÍ, 2003.

FOSTER, Hal (Comp.). La Posmodernidad. 5. ed. Barcelona: Kairós, 2002.

FOUCAULT, Michel. Em Defesa da Sociedade. Trad. de Maria Ermantina Galvão. São Paulo: Martins Fontes, 1999.

GUATTARI, Félix. Revolução Molecular - pulsações políticas do desejo. Trad. de Suely Rolnick. 2. ed. São Paulo: Brasiliense., 1985.

HABERMAS, Jürgen. O Discurso Filosófico da Modernidade. Trad. de Luiz Sérgio Repa e Rodnei Nascimento. São Paulo: Martins Fontes, 2002.

LIPOVETSKY, Gilles. Os tempos hipermodernos. Trad. de Mário Vilela. São Paulo: Barcarolla, 2004.

LYOTARD, Jean-François. O Pós-Moderno. Trad. de Ricardo Barbosa. Rio de Janeiro: José Olympio, 1986.

MARQUES, António. A Filosofia Perspectivista de Nietžsche. São Paulo: Discurso Editorial; Ijuí: GEN/Ed. UNIJUÍ, 2003.

NEGRI, Antonio; HARDT, Michael. Império. Rio de Janeiro: Record, 2001.

NIETZSCHE, Friedrich. A Gaia Ciência. Trad. de Maria Helena Rodrigues de Carvalho, Maria Leopoldina de Almeida e Maria Encarnação Casquinho. Lisboa: Relógio D’Água, 1998a.

Genealogia da Moral - uma polêmica. Tradução, notas e posfácio de Paulo César de Souza. São Paulo: Cia. das Letras, 1998b.

O Nascimento da Tragédia e Acerca da Verdade e da Mentira. Trad. de Teresa R. Cadete e Helga Hoock Quadrado. Lisboa: Relógio D’Água, 1997.

PETERS, Michael. Pós-estruturalismo e filosofia da diferença. Trad. de Tadeu Tomás de Souza. Belo Horizonte: Autêntica, 2000.

VATTIMO, Gianni. O Fim da Modernidade. Trad. de Eduardo Brandão. São Paulo: Martins Fontes, 1996.

Artigo recebido em 20/09/2007 - Aprovado em 10/06/2008 